\title{
Methodologies for assessing the household food availability in the context of food (in)security: a systematic review
}

\author{
Metodologias de avaliação da disponibilidade de alimentos \\ no domicílio no contexto da (in)segurança alimentar: uma revisão \\ sistemática
}

Eloise Schott (https://orcid.org/0000-0002-3852-1894) ${ }^{1}$

Fabiane Aparecida Canaan Rezende (https://orcid.org/0000-0002-5617-8778) ${ }^{1}$

Silvia Eloiza Priore (https://orcid.org/0000-0003-0656-1485) ${ }^{2}$

Andréia Queiroz Ribeiro (https://orcid.org/0000-0001-6546-1252) ${ }^{2}$

Sylvia do Carmo Castro Franceschini (https://orcid.org/0000-0001-7934-4858) ${ }^{2}$
${ }^{1}$ Curso de Nutrição, Universidade Federal do Tocantins. Quadra 109

Norte Avenida NS 15, Plano Diretor Norte. 77001-090

Palmas TO Brasil.

eloise@uft.edu.br

${ }^{2}$ Departamento de Nutrição

e Saúde, Centro de Ciências Biológicas e da Saúde,

Universidade Federal de

Viçosa. Viçosa MG Brasil.

\begin{abstract}
This article aims to identify the methods used to assess household food availability in studies on food and nutritional security and to discuss its methodological aspects. Systematic review elaborated according to the PRISMA method. We searched at PubMed; Scielo and Lilacs databases, and studies that used methods of assessing the availability of food at home were included. In the end, 19 papers composed the review. Food availability was predominantly assessed for a seven days period and from a single data measurement. Other variables were also observed in the studies, such as socio-demographic data and expenditure on food. Among the limitations to assess the food availability at home, we can highlight the difficulty in measuring the food distribution among family members and the lack of information on the variability of this availability. Such assessment can be improved by investigating the strengths and weaknesses of the instruments for greater detail and accuracy of the information. We recommend the development and validation of specific instruments capable of effectively measure the food availability at the household level. Key words Food and nutritional security, Systematic review, Food and beverages
\end{abstract}

Resumo $O$ objetivo deste artigo é identificar métodos empregados para a avaliação da disponibilidade de alimentos no âmbito domiciliar em estudos sobre segurança alimentar e nutricional e discutir seus aspectos metodológicos. Revisão sistemática elaborada segundo o método PRISMA. Realizou-se busca nas bases de dados PubMed, SciELO e Lilacs, tendo sido incluídos estudos que empregaram métodos de avaliação da disponibilidade de alimentos no domicílio. Ao final, 19 artigos compuseram a revisão. A disponibilidade de alimentos foi avaliada predominantemente para um período de sete dias e a partir de única medição dos dados. Outras variáveis também foram observadas nos estudos, como dados sociodemográficose de despesas com os alimentos. Dentre as limitações para a avaliação da disponibilidade domiciliar de alimentos, destaca-se a dificuldade de mensuração da distribuição de alimentos entre os membros da família e a falta de informação sobre a variabilidade desta disponibilidade. Tal avaliação pode ser melhorada através da investigação de pontos fortes e fracos dos instrumentos para maior detalhamento e precisão das informações. Recomenda-se o desenvolvimento e a validação de instrumentos específicos capazes de mensurar efetivamente a disponibilidade de alimentos em nivel domiciliar. Palavras- chave Segurança alimentar e nutricional, Revisão sistemática, Alimentos e bebidas 


\section{Introduction}

According to the Food and Agriculture Organization of the United Nations (FAO) recommendations, regular access to sufficient, safe and nutritious food information is required to ensure food security, in order to meet individual nutritional preferences and needs for a healthy and active life ${ }^{1}$.

Therefore, food insecurity occurs when there is limited or uncertain availability and/or ability to have nutritionally adequate and safe food $^{2}$. Availability and access to healthy food are required for promoting individual health and nutrition ${ }^{3}$, and are achieved when enough food is available to all individuals, whether from the production for self-consumption, shopping or donations ${ }^{4}$. However, food may be available, but not accessible to the population, due to socioeconomic limitations or other factors such as food monopoly, leading to Food and Nutritional Insecurity ${ }^{5}$.

The household environment has a great implication on the food intake ${ }^{6}$, such that the food found in the pantries are indicators of the family's actual food consumption ${ }^{7}$. Different methods for measuring household food availability have been developed and applied in the last years, but frequency of observations, types of food and data collection procedures vary from one method to another ${ }^{8}$, and the data availability can be collected from direct observation at home, considered the "gold standard", or through self-reporting, according to instruments proposed for this purpose, by telephone or mail 9 .

Nonetheless, only with adequate measurement tools will it be possible to better understand the causes of food insecurity, identify the most vulnerable populations, determine effective mechanisms to solve the problem and assess the impact of possible interventions ${ }^{2}$.

Therefore, assessing the food availability at household is essential to assess food insecurity ${ }^{10}$. For that reason, this literature review proposes to identify, the methods used to assess the household food availability in studies on food and nutritional security and to discuss its methodological aspects.

\section{Methods}

It is a systematic review of the literature, arranged according to the Preferred Reporting Items for Systematic Reviews and Meta Analyzes (PRIS-
MA) Guide ${ }^{11}$ based on food safety studies that used methods of assessing the food availability at home. The PICO strategy (Problem, Intervention, Comparasion, Outcomes) was employed for the construction of the guiding question of the research which was: "What are the methods employed for the assessment of the availability of household foods in studies in the context of food and nutritional security?" The literature review was done independently, in September 2018, from the selection of studies published in PubMed; SciELO and Lilacs databases, using the same search criteria for all bases. The following combinations were used to search the articles: "food availability" OR "food available" AND "food security" and "food availability" OR "food available" AND "food insecurity", including articles published in English and Spanish, without limitation regarding the period of publication, in order to contemplate the scientific production until the moment of the research. For the manuscripts that did not provide sufficient information from their title and abstract, we proceeded to full reading, where we extracted information about the population and the type of study, the methods and limitations. Subsequently, we searched the gray literature, employing the same terms described, in databases that index this type of literature (http://www.dominiopublico.gov.br and http: //www.periodicos.capes.gov.br). The references of the eligible studies were analyzed to find other publications of interest.

The quality of the studies was not analyzed, since the review does not intend to assess the results, and only, identifies the methods proposed by them. The original articles, as well as dissertations and theses that used methods of assessing the availability of food at home were included in the review. Review studies, experimental studies with animals or plants, and studies assessing the availability of food outside home were excluded.

In order to verify the methods of assessing the availability of food at home, we elaborated an instrument that could synthesize the main data extracted from each study in a descriptive way (Chart 1), containing the following components: author, year and local of publication, study design, sample size, method and period of assessing food availability.

\section{Results}

The Figure 1 shows the flowchart of the studies selection to compose the research. The search re- 
Chart 1. Summary of the methodological aspects of the studies that assessed food availability at the household level $(\mathrm{n}=19)$.

\begin{tabular}{|c|c|c|c|c|c|}
\hline Author/year & Local & Study design & $\begin{array}{l}\text { Sample } \\
\text { size }\end{array}$ & Method of assessing food availability & $\begin{array}{c}\text { Time of } \\
\text { assessing } \\
\text { the } \\
\text { availability }\end{array}$ \\
\hline $\begin{array}{l}\text { Dutra, et al. } \\
2018\end{array}$ & Brazil & $\begin{array}{l}\text { cross- } \\
\text { sectional } \\
\text { study }\end{array}$ & $\begin{array}{l}79 \\
\text { households }\end{array}$ & $\begin{array}{l}\text { Questionnaire applied by the interviewer } \\
\text { containing a food list used to estimate the } \\
\text { household food availability, recording the } \\
\text { quantity and the origin of this acquisition. }\end{array}$ & Thirty days \\
\hline $\begin{array}{l}\text { Bruening } \\
\text { et al. } \\
2017\end{array}$ & $\begin{array}{l}\text { United } \\
\text { States }\end{array}$ & $\begin{array}{l}\text { cross- } \\
\text { sectional } \\
\text { study }\end{array}$ & $\begin{array}{l}54 \\
\text { households }\end{array}$ & $\begin{array}{l}\text { Inventory applied by the interviewer to } \\
\text { estimate the household food availability } \\
\text { (yes/no). } 29 \text { items divided into } 10 \\
\text { subgroups. }\end{array}$ & $\begin{array}{l}\text { At the } \\
\text { time of the } \\
\text { interview }\end{array}$ \\
\hline $\begin{array}{l}\text { Nunnery; } \\
\text { Labban; } \\
\text { Dharod } \\
2017\end{array}$ & $\begin{array}{l}\text { United } \\
\text { States }\end{array}$ & $\begin{array}{l}\text { cross- } \\
\text { sectional } \\
\text { study }\end{array}$ & $\begin{array}{l}198 \\
\text { individuals }\end{array}$ & $\begin{array}{l}\text { Inventory applied by the interviewer to } \\
\text { estimate the household availability of } \\
\text { fruits and vegetables (yes/no). } 44 \text { items } \\
\text { divided into subgroups: fresh, dried, } \\
\text { canned or frozen products. }\end{array}$ & Seven days \\
\hline Peter, 2016 & Brazil & $\begin{array}{l}\text { cross- } \\
\text { sectional } \\
\text { study }\end{array}$ & $\begin{array}{l}1126 \\
\text { households }\end{array}$ & $\begin{array}{l}\text { Self-administered questionnaire } \\
\text { answered by parents/guardians to assess } \\
\text { the food availability (never; almost } \\
\text { never; sometimes; almost always; } \\
\text { always), recording the origin and form } \\
\text { of acquisition. } 14 \text { food items divided } \\
\text { into } 4 \text { subgroups. }\end{array}$ & Thirty days \\
\hline $\begin{array}{l}\text { Emery, et al. } \\
2015\end{array}$ & $\begin{array}{l}\text { United } \\
\text { States }\end{array}$ & $\begin{array}{l}\text { cross- } \\
\text { sectionalstudy }\end{array}$ & $\begin{array}{l}100 \\
\text { individuals }\end{array}$ & $\begin{array}{l}\text { Inventory applied by the interviewer to } \\
\text { estimate the availability of household } \\
\text { stored food. }\end{array}$ & $\begin{array}{l}\text { At the } \\
\text { time of the } \\
\text { interview }\end{array}$ \\
\hline $\begin{array}{l}\text { Dutra, et al. } \\
2014\end{array}$ & Brazil & $\begin{array}{l}\text { cross- } \\
\text { sectional } \\
\text { study }\end{array}$ & $\begin{array}{l}10 \\
\text { households }\end{array}$ & $\begin{array}{l}\text { Questionnaire applied by the interviewer } \\
\text { containing a food list used to estimate the } \\
\text { household food availability, recording the } \\
\text { quantity and the origin of this acquisition. }\end{array}$ & Thirty days \\
\hline $\begin{array}{l}\text { Soares, et al. } \\
2014\end{array}$ & Brazil & $\begin{array}{l}\text { cross- } \\
\text { sectional } \\
\text { study }\end{array}$ & $\begin{array}{l}1555 \\
\text { households }\end{array}$ & $\begin{array}{l}\text { Self-administered questionnaire } \\
\text { answered by the head of the family } \\
\text { to assess the food availability, (never; } \\
\text { occasionally; sometimes; usually; always) } \\
\text { and origin of the acquisition of fruits } \\
\text { and vegetables. } 8 \text { food items }\end{array}$ & Thirty days \\
\hline $\begin{array}{l}\text { Valencia- } \\
\text { Valero; } \\
\text { Ortiz- } \\
\text { Hernández. } \\
2014\end{array}$ & Mexico & $\begin{array}{l}\text { descriptive } \\
\text { (database } \\
\text { analysis) }\end{array}$ & $\begin{array}{l}27445 \\
\text { households }\end{array}$ & $\begin{array}{l}\text { Daily record of expenditure information } \\
\text { on food and beverages purchased; food } \\
\text { and beverages obtained as work payment } \\
\text { or donation. The person responsible for } \\
\text { the purchase registered the name and } \\
\text { quantity of each food or beverage. }\end{array}$ & Seven days \\
\hline $\begin{array}{l}\text { Wilson, et al. } \\
2014\end{array}$ & $\begin{array}{l}\text { New } \\
\text { Zealand }\end{array}$ & $\begin{array}{l}\text { prospective } \\
\text { longitudinal } \\
\text { study }\end{array}$ & $\begin{array}{l}216 \\
\text { individuals }\end{array}$ & $\begin{array}{l}\text { Self-administered questionnaire } \\
\text { answered by the participant to assess the } \\
\text { household food availability. } 351 \text { food } \\
\text { items divided into } 13 \text { subgroups. }\end{array}$ & $\begin{array}{l}\text { At the } \\
\text { time of the } \\
\text { interview }\end{array}$ \\
\hline $\begin{array}{l}\text { Martins, } \\
2013\end{array}$ & Brazil & $\begin{array}{l}\text { quasi- } \\
\text { experiment } \\
\text { study } \\
\text { (database } \\
\text { analysis) } \\
\end{array}$ & $\begin{array}{l}11326 \\
\text { households }\end{array}$ & $\begin{array}{l}\text { Self-administered questionnaire } \\
\text { answered by the householdresidents, } \\
\text { and when necessary, by the interviewer, } \\
\text { to assess the availability, quantity, origin } \\
\text { and expenditure of food and beverages. }\end{array}$ & Seven days \\
\hline
\end{tabular}


Chart 1. Summary of the methodological aspects of the studies that assessed food availability at the household level $(\mathrm{n}=19)$.

\begin{tabular}{|c|c|c|c|c|c|}
\hline Author/year & Local & Study design & $\begin{array}{l}\text { Sample } \\
\text { size }\end{array}$ & Method of assessing food availability & $\begin{array}{c}\text { Time of } \\
\text { assessing } \\
\text { the } \\
\text { availability }\end{array}$ \\
\hline $\begin{array}{l}\text { Levy, et al. } \\
2012\end{array}$ & Brazil & $\begin{array}{l}\text { descriptive } \\
\text { (database } \\
\text { analysis) }\end{array}$ & $\begin{array}{l}55970 \\
\text { households }\end{array}$ & $\begin{array}{l}\text { Self-administered questionnaire } \\
\text { answered by the householdresidents, } \\
\text { and when necessary, by the interviewer, } \\
\text { to assess the availability, quantity, origin } \\
\text { and expenditure of food and beverages. } \\
334 \text { items, divided into } 15 \text { subgroups. }\end{array}$ & Seven days \\
\hline $\begin{array}{l}\text { Bauer, et al. } \\
2012\end{array}$ & $\begin{array}{l}\text { United } \\
\text { States }\end{array}$ & $\begin{array}{l}\text { randomized } \\
\text { controlled } \\
\text { trial }\end{array}$ & $\begin{array}{l}432 \\
\text { households }\end{array}$ & $\begin{array}{l}\text { Inventory applied by the interviewer to } \\
\text { estimate the household availability of } \\
\text { fruits, vegetables, beverages, snacks and } \\
\text { food with high energy density (yes/no). }\end{array}$ & Seven days \\
\hline $\begin{array}{l}\text { Sharkey, } \\
\text { et al. } \\
2010\end{array}$ & $\begin{array}{l}\text { United } \\
\text { States }\end{array}$ & $\begin{array}{l}\text { cross- } \\
\text { sectional } \\
\text { study (pilot) }\end{array}$ & $\begin{array}{l}06 \\
\text { households }\end{array}$ & $\begin{array}{l}05 \text { Inventories applied by the interviewer } \\
\text { to estimate the household availability and } \\
\text { quantity of food and beverages. } 252 \text { items. }\end{array}$ & Thirty days \\
\hline $\begin{array}{l}\text { Sisk, et al. } \\
2010\end{array}$ & $\begin{array}{l}\text { United } \\
\text { States }\end{array}$ & $\begin{array}{l}\text { cross- } \\
\text { sectional } \\
\text { study (pilot) }\end{array}$ & $\begin{array}{l}09 \\
\text { households }\end{array}$ & $\begin{array}{l}05 \text { Inventories applied by the interviewer } \\
\text { to estimate the household availability } \\
\text { and quantity of food and beverages. } 251 \\
\text { items }\end{array}$ & Thirty days \\
\hline $\begin{array}{l}\text { Baranowski, } \\
\text { et al. } \\
2008\end{array}$ & $\begin{array}{l}\text { United } \\
\text { States }\end{array}$ & $\begin{array}{l}\text { cross- } \\
\text { sectional } \\
\text { study }\end{array}$ & $\begin{array}{l}162 \\
\text { individuals }\end{array}$ & $\begin{array}{l}\text { The availability of fruit, juice and } \\
\text { vegetables was assessed. } 35 \text { items were } \\
\text { identified as (yes or no). }\end{array}$ & Seven days \\
\hline $\begin{array}{l}\text { Hackett, et } \\
\text { al. } 2007\end{array}$ & Ecuador & $\begin{array}{l}\text { cross- } \\
\text { sectional } \\
\text { study }\end{array}$ & $\begin{array}{l}52 \\
\text { households }\end{array}$ & $\begin{array}{l}\text { Inventory applied by the interviewer to } \\
\text { estimate the household food availability. } \\
\text { Divided into } 11 \text { subgroups. }\end{array}$ & $\begin{array}{l}\text { At the } \\
\text { time of the } \\
\text { interview }\end{array}$ \\
\hline $\begin{array}{l}\text { Pérez-Cueto, } \\
\text { et al. } \\
2006\end{array}$ & Bolivia & $\begin{array}{l}\text { cross- } \\
\text { sectional } \\
\text { studies } \\
\text { (database } \\
\text { analysis) } \\
\end{array}$ & $\begin{array}{l}19483 \\
\text { households }\end{array}$ & $\begin{array}{l}\text { Frequency questionnaire applied by } \\
\text { the interviewer recording quantity } \\
\text { and expenses on purchases and own } \\
\text { production of food and beverages. } 60 \\
\text { items. }\end{array}$ & Four weeks \\
\hline $\begin{array}{l}\text { Lorenzana; } \\
\text { Sanjur. } \\
1999 \\
\end{array}$ & Venezuela & $\begin{array}{l}\text { cross-sectional } \\
\text { study }\end{array}$ & $\begin{array}{l}238 \\
\text { households }\end{array}$ & $\begin{array}{l}\text { Checklist applied by the interviewer to } \\
\text { estimate the household food availability }\end{array}$ & Seven days \\
\hline $\begin{array}{l}\text { Kendall, et } \\
\text { al. } 1996\end{array}$ & $\begin{array}{l}\text { United } \\
\text { States }\end{array}$ & $\begin{array}{l}\text { cross- } \\
\text { sectional } \\
\text { study }\end{array}$ & $\begin{array}{l}193 \\
\text { individuals }\end{array}$ & $\begin{array}{l}02 \text { Inventories applied by the interviewer } \\
\text { to estimate the household availability } \\
\text { and quantity of food. } 51 \text { items }\end{array}$ & $\begin{array}{l}\text { At the } \\
\text { time of the } \\
\text { interview }\end{array}$ \\
\hline
\end{tabular}

sulted in 139 papers. The titles and abstracts of the papers were read to identify those that met the inclusion criteria to assess eligibility. In total, 129 papers were excluded, of which 30 were repeated papers, 11 were clinical studies, with food or animal, 21 were review or report papers, 40 took a broad approach to food security, but without assessing the availability or assess it outside the home.

After reading the full text manuscripts assessed for eligibility, we verified that 27 studies were conducted in households, but did not address the food availability. With this, there were
10 eligible papers. Subsequently, the research in the gray literature resulted in the inclusion of 02 documents. Ultimately, a reverse search was performed based on the references of the selected papers, and with that 07 studies were included. Thus, 19 studies met the established selection criteria and composed this review.

Of all eligible studies, one was conducted in Mexico $^{12}$, one in Venezuela ${ }^{13}$, one in Bolivia ${ }^{14}$, eight in the United States ${ }^{715-21}$, six in Brazil ${ }^{22-27}$, one in Ecuador ${ }^{28}$, and one in New Zealand ${ }^{29}$. Twelve of them once applied the instrument to assess food availability ${ }^{13,14,17-20,22,23,26-29}$, two 


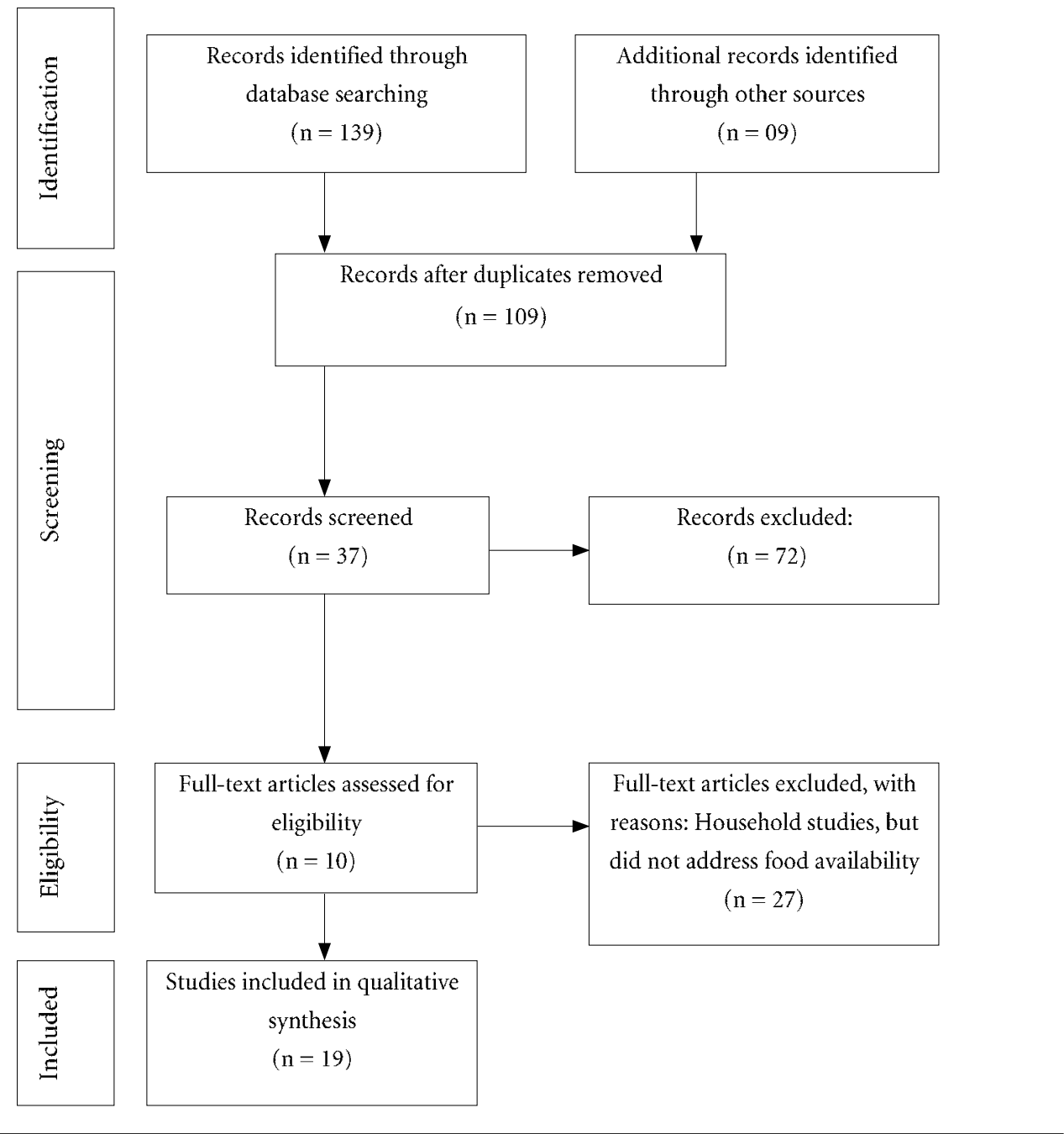

Figure 1. Flowchart of the search and selection of the papers for the systematic review.

studies performed 5 availability records for 30 days, with a 7 -day interval ${ }^{15,16}$, one study applied the instrument twice, with a 6-week interval ${ }^{7}$, one study applied the instrument twice, with a 3 -week interval ${ }^{21}$ three studies used record to assess availability for 7 days ${ }^{12,24,25}$. Food availability was predominantly assesses for a period of seven days ${ }^{7,12,13,17-20,24,25}$.

The information obtained by the authors from the instruments used is summarized as: food and/or beverages availability at home ${ }^{13,15-}$ 18,20-23,26-29, availability and expenses with food and/or beverages at home $e^{12,14,24,25}$, fruits and vegetables availability at home ${ }^{7,19}$.

Regarding the number of items assessed, five studies verified the availability of all food stored at home ${ }^{12,13,17,18,24}$ and fourteen studies used instruments with a certain number of food and beverages, in eleven ranging from 14 to 351 items ${ }^{7,14-16,19-21,25-27,29}$, and three studies did not present the number of items contained in the instrument ${ }^{22,23,28}$. In thirteen studies the instruments were applied by the interviewer ${ }^{7,13-23,28}$, and in six, the record was filled by the person responsible for buying food/beverages at home ${ }^{12,24-27,29}$. Ten studies reported availability and quantity of food and/or beverages at home, ${ }^{12,14-16,21,23-25,28}$, others focused only on availability $7,13,17-20,26,27,29$

In addition to assessing food availability, other variables of interest were observed in the studies, which include sociodemographic data, such as information on the head of the fam- 
ily/interviewee $e^{7,12-19,21,22,24,25,27-29}$, family members ${ }^{12-18,20-24,26-28}$, employment and/or family income ${ }^{12-17,21,22,24,25,27,29}$, food expenses ${ }^{13,14,24}$, participation of the individuals and families in welfare programs or government aid ${ }^{12,15-19,21,22,24,28,29}$, food consumption ${ }^{14,18,19,21}$, food habits $13,15-17,21$, body composition of the individuals ${ }^{17,18,20,22,23,29}$, biochemical tests ${ }^{18}$, household conditions ${ }^{22,24,28}$, basic sanitation ${ }^{22}$, geographical locations of household $s^{24,25}$, food and animal cultivation ${ }^{28}$, and life standard ${ }^{29}$.

In relation to the assessment of household Food and Nutrition Security, of the selected papers, one made use of the Latin American and Caribbean Food Security Scale (ELCSA) ${ }^{12}$,-two used the Household Food Security Survey (HFSS) ${ }^{19,28}$, four used the HFSS reduced version ${ }^{15-18}$, one used the Community Childhood Hunger Identification Project (CCHIP) ${ }^{13}$, and one used the Radimer/Cornell food insecurity items ${ }^{21}$. All are validated psychometric scales that indicate whether adults or children in the same family experience food shortages or deprivation and modify food intake due to financial resource limitations ${ }^{12,13,16}$.

Other studies did not directly assess household

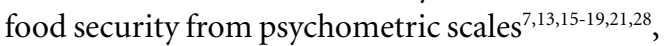
whereas, one used family expenditure on food as a proxy for income, considering it a measure of intra-familiar food security ${ }^{14}$, e two assessed the situation of food insecurity in households using the concept of "household food energy availability" according to the method proposed by $\mathrm{FAO}^{22,23}$. Since food availability varies according to socioeconomic conditions, family composition, household location, and may compromise Food and Nutritional Security ${ }^{26}$, the other studies were included for assessing these aspects, such as the availability of fruits and vegetables at homes with children ${ }^{7}$, or food availability in households with children in rural areas ${ }^{26}$, the food availability of families receiving a supplementary nutritional assistance program ${ }^{20,24}$ and household availability of food according to socioeconomic and demographic factors ${ }^{25,27,29}$.

\section{Discussion}

It was observed a predominance of only a single measurement of food availability $^{7-9,14,17,18,20,22,23,26-29}$. Some methods of assessing household food availability are sometimes impracticable due to their extension and the need for sufficient human and financial resources. Therefore, reduced instruments may be useful for this analysis ${ }^{13,15}$. On the other hand, a single application can generate biases and misinterpretations about household food availability, presenting an imprecise description of the food available for consumption ${ }^{15,16}$, furthermore, the use of instruments with a limited number of items does not reliably determine the quantity or quality of the food available ${ }^{16,17}$.

Food availability may be affected by a series of irregular events including family parties, acute illness, and times of family difficulty. Using several measures, it is possible to better observe the impact of these events, as well as intra-family variability ${ }^{16}$. Researches investigating, in greater detail, the food availability may improve the assessment of these aspects, which are susceptible to variations according to the family situation ${ }^{16,17}$.

This highlights the importance of multiple measures of food availability and the feasibility of more extensive assessments ${ }^{16}$. Which allows information obtainment on the weekly change in availability and the presence and quantity of specific foods, noting that the number of measures and the most appropriate period of time for application of the instruments depend on their purpose $^{15}$.

Other authors focus their instruments on assessing the availability of certain types of food to achieve a specific objective, such as the household availability of fruit and vegetables ${ }^{7,19}$, or special situations, such as the availability of food for cancer prevention, cardiovascular diseases ${ }^{30}$, Human Immunodeficiency Virus (HIV) care $^{31}$. However, due to data limitations, the measurement of a greater variety of foods seems to be more complete and with satisfactory validity9.

Regarding the relationship between food security and food availability, the availability, access, use of the food and the stability are recognized as the pillars of food security ${ }^{32}$ and when one of these aspects is violated, it is characterized food and nutritional insecurity ${ }^{33}$. Besides being among the main determinants of the food sys$\mathrm{tem}^{34}$, household availability is influenced by several factors, such as composition and family income, storage conditions and access to food commercialization establishments ${ }^{16}$, production for self consumption ${ }^{22}$, regional production and infrastructure of the food system such as stock and transportation ${ }^{32}$.

Unsatisfactory socioeconomic conditions such as low income $e^{13,15,17,25,29}$ and low education of the head of the family ${ }^{12,25}$ are also negatively related to food security and food availability. Insecure food households have less availability of 
most food ${ }^{12,17,19,28,29}$. In contrast, the food production for self-consumption positively influences

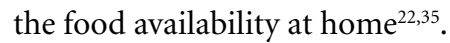

We also emphasize that four studies assessed secondary data on household food availability from food surveys of national representativity ${ }^{12,14,24,25}$. Surveys such as these that produce information at the national level, regarding household food availability enable the characterization of the temporal changes in the population's feeding, and contribute with information on the adequacy of the composition of families' feeding ${ }^{25}$, in addition to its use for nutritional surveillance, elaboration and assessment of public policies ${ }^{14}$.

We can highlight the importance of the use of validated methods for assessing the household food availability is highlighted. The development of several household measurement instruments does not include comprehensive validity tests, and validity is a fundamental criterion, since an instrument should be associated with the expected results of the study ${ }^{13}$.

A suggested method for assessing the validity of food availability instruments is the completion of the instrument by the research participants, and then their answers are compared with the questionnaire applied by the researcher (gold standard). The comparisons are assessed regarding the consistency of the results, using statistical method or through the analysis of sensitivity and specificity $^{30}$.

Household food availability is associated with ingestion, habit and dietary patterns ${ }^{19,30}$, and, although important results of home-based surveys are observed, they have the limitation of not knowing the individual food consumption ${ }^{22,24}$, since they do not assess the dietary intake of each family member or characteristics such as weight, height and level of physical activity in order to determine the appropriate individual intake. Such information could point to a more accurate perspective of the Food and Nutrition Security situation $^{12,36}$.

Other limitations observed in methods of assessing food availability are the short assessment period and the variety of foods covered in the instruments, since from a food and nutritional security perspective, feeding is adequate when offered in sufficient quantity and quality and permanently, thus, a less comprehensive assessment may be a bias in determining the food available and its variation at home over a longer period. Moreover, socioeconomic and cultural aspects, not always addressed in the studies, are determinants on food and nutritional security, therefore, besides food availability, assessing these factors becomes important for a better understanding of the conditions and consequences of feeding and food and nutritional (in)security of the population.

The use of only three databases is considered a limiting factor of this review, with this, possible eligible publications may not have been identified. Despite the gray literature survey, it was restricted to the bases indicated in the methodology. As the gray literature is difficult to systematize the search, it is possible that some study related to the theme of the review has not been contemplated. However, despite the limitations, we believe that it was possible to critically demonstrate and discuss the main methods employed in the assessment of food availability in the households in studies related to Food and Nutritional Security.

\section{Considerations and recommendations}

It was observed that the majority of the studies opted for assessing the food availability from a single application of the instrument, containing as main information the quantity and quality of the food purchased in the households, almost always followed by the Food Security measurement.

Among the limitations to assess the household food availability, the difficulty of measuring the food distribution between family members is highlighted, as well as the lack of information on monthly, intra- and inter-personal variability of food availability. However, the availability assessment can be improved by investigating the strengths and weaknesses of the instruments for further detail and accuracy of the information.

As the household food availability is influenced by several factors, it is of extreme importance that these are also taken into account in the studies. The relevance of household food availability assessment is due both to its close relation with food security and to its determinant role in the family choices, habits and food consumption.

Whenever possible, we recommend the use of methods involving a wide variety of food and a longer time to assess availability, in order to better observe the variability and stability of food availability at home. The importance of the development and validation of specific instruments for the different populations capable of effectively measuring the availability of food at the household level is also emphasized. 


\section{Collaborations}

E Schott worked on the design, research, methodology and final writing; FAC Rezende worked on the design, methodology and final writing; SCC Franceschini worked on the design; methodology, final writing and on the approval of the version to be published; SE Priore and AQ Ribeiro worked on the final revision to be published.

\section{References}

1. Yang R-Y, Hanson PM. Improved food availability for food security in Asia-Pacific region. Asia Pac J Clin Nutr 2009; 18(4):633-637.

2. Comité Científico de la ELCSA. Escala Latinoamericana de Seguridad Alimentaria (ELCSA): manual de uso y aplicaciones. Santiago de Chile: Organización de las Naciones Unidas para la Agricultura y la Alimentación; 2012.

3. Lunze K, Yurasova E, Idrisov B, Gnatienko N, Migliorini L. Food security and nutrition in the Russian Federation a health policy analysis. Global Health Action 2015; 8:27537.

4. Riely F, Mock N, Cogill B, Bailey L, Kenefick E. Food Security Indicators and Framework for Use in the Monitoring and Evaluation of Food Aid Programs. Arlington: Food Security and Nutrition Monitoring Project (IMPACT), ISTI, Inc., for the U.S. Agency for International Development; 1999.

5. Belik W. Perspectivas para segurança alimentar e nutricional no Brasil. Saúde Soc. 2003; 12(1):12-20.

6. Byrd-Bredbenner C, Abbot JM, Cussler E. Nutrient Profile of Household Food Supplies of Families with Young Children. J Am Diet Assoc 2009; 109(12):20572062.

7. Baranowski T, Missaghian M, Watson K, Broadfoot A, Cullen K, Nicklas T, Fisher J, O’Donnell S. Home fruit, juice, and vegetable pantry management and availability scales: A validation. Appetite 2008; 50(23):266-277.

8. Satia J, Galanko J. Comparison of three methods of measuring dietary fat consumption by African-American adults. J Am Diet Assoc 2007; 107(5):782-791.

9. French SA, Shimotsu ST, Wall M, Gerlach AF. Capturing the Spectrum of Household Food and Beverage Purchasing Behavior: A Review. J Am Diet Assoc 2008; 108(12):2051-2058.

10. Osório MM, Ribeiro MA, Costa EC, Silva SPO, Fernandes CE. Disponibilidade familiar de alimentos na Zona da Mata e Semi-Árido do Nordeste do Brasil. Rev Nutr 2009; 22(3):319-329.

11. Moher D, Liberati A, Tetzlaff J, Altman DG; The PRISMA Group (2009). Preferred Reporting Items for Systematic Reviews and Meta-Analyses: The PRISMA Statement. PLoS Med 6(7):e1000097.

12. Valencia-Valero RG, Ortiz-Hernández L. Disponibilidad de alimentos en los hogares mexicanos de acuerdo con el grado de inseguridad alimentaria. Salud Publica Mex 2014; 56(2):154-164.

13. Lorenzana PA, Sanjur D. Abbreviated Measures of Food Sufficiency Validly Estimate the Food Security Level of Poor Households: Measuring Household Food Security. J Nutr 1999; 129(3):687-692.

14. Pérez-Cueto FJ, Naska A, Monterrey J, Almanza-Lopez M, Trichopoulou A, Kolsteren P. Monitoring food and nutrient availability in a nationally representative sample of Bolivian household. Br J Nutr 2006; 95(3):555-567. 
15. Sharkey JR, Dean WR, St John JA, Huber JC Jr. Using direct observations on multiple occasions to measure household food availability among low-income Mexicano residents in Texas colonias. BMC Public Health 2010; 10:445.

16. Sisk C, Sharkey JR, McIntosh WA, Anding J. Using multiple household food inventories to measure food availability in the home over 30 days: a pilot study. Nutr J 2010; 9:19.

17. Bauer KW, Widome R, Himes JH, Smyth M, Rock BH, Hannan PJ, Story M. High Food Insecurity and Its Correlates Among Families Living on a Rural American Indian Reservation. Am J Public Health 2012; 102(7):1346-1352.

18. Emery CF, Olson KL, Lee VS, Habash DL, Nasar JL, Bodine A. Home environment and psychosocial predictors of obesity status among community-residing men and women. Int J Obes (Lond) 2015; 39(9):14011407.

19. Nunnery DL, Labban JD, Dharod JM. Interrelationship between food security status, home availability of variety of fruits and vegetables and their dietary intake among low-income pregnant women. Public Health Nutr 2017; 21(4):807-815.

20. Bruening M, McClain D, Moramarco M, Reifsnider E. The Role of SNAP in Home Food Availability and Dietary Intake among WIC Participants Facing Unstable Housing. Public Health Nurs 2017; 34(3):219-228.

21. Kendall A, Oslon CM, Frongillo EA. Relationship of hunger and food insecurity to food availability and consumption. J Am Diet Assoc 1996; 96(10):10191024.

22. Dutra LV, Morais DC, Santos RHS, Franceschini SCC, Priore SE. Contribution of the production for self-consumption to food availability and food security in households of the rural area of a Brazilian city. Ecol Food Nutr 2018; 57(4):282-300.

23. Dutra LV, Souza LM, Santos RHS, Priore SE. Disponibilidade alimentar para famílias residentes na zona rural: Situação de segurança ou insegurança alimentar e nutricional. Segur Aliment Nutr 2014; 21(1):320329.

24. Martins APB. Impacto do Programa Bolsa Família sobre a aquisição de alimento em famílias brasileiras de baixa renda [tese]. São Paulo: Faculdade de Saúde Pública; 2013.

25. Levy RB, Claro RM, Mondini L, Sichieri R, Monteiro CA. Distribuição regional e socioeconômica da disponibilidade domiciliar de alimentos no Brasil em 20082009. Rev Saude Publica 2012; 46(1):6-15.

26. Peter NB. Disponibilidade de alimentos no domicílio de escolares da zona rural de Pelotas [dissertação]. Pelotas: Universidade Federal de Pelotas; 2016.

27. Soares ALG, França GVA, Gonçalves H. Household food availability in Pelotas, Brazil: An approach to assess the obesogenic environment. Rev Nutr 2014; 27(2):193-203.
28. Hackett $M$, Zubieta AC, Hernandez $K$, Melgar-Quiñonez H. Food insecurity and household food supplies in rural Ecuador. Arch Latinoam Nutr 2007; 57(1):1-11.

29. Wilson R, Gearry RB, Grant E, Pearson J, Skidmore PML. Home food availability is associated with multiple socio-economic indicators in 50 year olds from Canterbury, New Zealand. Asia Pac J Clin Nutr 2014; 23(4):714-722.

30. Fulkerson JA, Nelson MC, Lytle L, Moe S, Heitzler C, Pasch KE. The validation of a home food inventory. Int J Behav Nutr Phys Act 2008; 5:55.

31. Anema A, Fielden SJ, Castleman T, Grede N, Heap A, Bloem M. Food Security in the Context of HIV: Towards Harmonized Definitions and Indicators. AIDS Behav 2014; 18(Supl. 5):476-489.

32. Harris-Fry H, Azad K, Kuddus A, Shaha S, Nahar B, Hossen M, Younes L, Costello A, Fottrell E. Socio-economic determinants of household food security and women's dietary diversity in rural Bangladesh: a cross-sectional study. J Health Popul Nutr 2015; 33:2.

33. Rocha NP, Milagres LC, Novaes JF, Franceschini SCC Associação de insegurança alimentar e nutricional com fatores de risco cardiometabólicos na infância e adolescência: uma revisão sistemática. Rev Paul Pediatr 2016; 34(2):225-233

34. Premanandh J. Factors affecting food security and contribution of modern technologies in food sustainability. J Sci Food Agric 2011; 91(15):2707-2714.

35. Walsh CM, Van Rooyen FC. Household Food Security and Hunger in Rural and Urban Communities in the Free State Province, South Africa. Ecol Food Nutr 2015; 54(2):118-137.

36. Murphy S, Ruel M, Carriquiry A. Should Household Consumption and Expenditures Surveys (HCES) be used for nutritional assessment and planning? Food Nutr Bull 2012; 33(Supl. 3):235-241.

Article submitted 08/03/2018

Approved 26/11/2018

Final version submitted 28/11/2018 
